\title{
Pre-Departure Training and Personal Resources: How it Affects Acculturative Stress?
}

\author{
Widayanti ${ }^{*}$, Dina Sartika ${ }^{2}$ \\ *Corresponding author
}

\begin{abstract}
One of the efforts made by the government to reduce the unemployment rate in Indonesia is by conducting an overseas apprenticeship program. As an international assignment, this apprenticeship program leads to social problems such as stress. This research seeks to examine and analyze the influence of pre-departure training on acculturative stress with personal resources as a moderating variable. The respondents of this study were 215 migrant workers from West Java. This research used process analysis to analyze data. The result shows that there is a negative influence of pre-departure training on acculturative stress. Whereas, personal resources strengthen the influence of pre-departure training on acculturative stress. The higher a level of personal resources possessed, the more it will strengthen the influence of pre-departure training on acculturative stress. These findings support the statement that personal resources are one of the leading indicators that affect an individual's performance at work.
\end{abstract}

Keywords: pre-departure training, acculturative stress, personal resources, migrant workers JEL Classification: M53, J61

\begin{abstract}
Abstrak. Salah satu upaya pemerintah dalam menekan tingkat pengangguran yaitu dengan mengadakan program pemagangan di luar negeri. Sebagai penugasan internasional, program pemagangan ini tidak terlepas dari permasalahan sosial seperti stres yang dialami oleh pekerja migran. Penelitian ini bertujuan untuk mengkaji dan menganalisis pengaruh pelatihan sebelum pemberangkatan terhadap stres akulturatif dengan sumber daya pribadi sebagai variabel moderasi. Responden pada penelitian ini yaitu 215 pekerja migran asal Jawa Barat. Penelitian ini menggunakan analisis proses untuk menguji dan menganalisis data yang telah diperoleh. Hasil dari penelitian ini menunjukkan bahwa pelatihan sebelum pemberangkatan memiliki pengaruh negatif terhadap stres akulturatif. Kemudian, sumber daya pribadi memperkuat pengaruh pelatihan sebelum pemberangkatan terhadap stres akulturatif. Semakin tinggi tingkat sumber daya pribadi yang dimiliki, maka semakin memperkuat pengaruh pelatihan sebelum pemberangkatan terhadap stres akulturatif. Temuan dari penelitian ini mendukung pernyataan bahwa sumber daya pribadi merupakan salah satu indikator utama yang mempengaruhi kinerja individu di lingkungan kerja.
\end{abstract}

Kata Kunci: pelatihan sebelum pemberangkatan, sumber daya pribadi, stres akulturatif, pekerja migran

\section{How to Cite:}

Widayanti., \& Sartika, D. (2020). Pre-Departure Training and Personal Resources: How it Affects Acculturative Stress?. Etikonomi: Jurnal Ekonomi, 19(1), 31 - 40. https://doi.org/10.15408/etk.v19i1.11884. 


\section{Introduction}

The problem of unemployment has been a significant problem for a long time. According to the Central Statistics Agency, until February 2018, the number of workforces in Indonesia had reached 133.94 million. It increased by 2.9 million compared to the previous year, while the open unemployment rate in Indonesia reached $5.13 \%$ or reduced by around 140 thousand people compared to last year. This unemployment rate has been the lowest unemployment rate since the 1998 crisis (Katadata.co.id, 2018). This trend is evidence that the labor market in Indonesia is growing.

Although the unemployment rate in Indonesia has decreased, the problem of unemployment remains a challenge for the government to reduce unemployment. One of the efforts made by the government to reduce the unemployment rate in Indonesia is by conducting an apprenticeship program abroad, namely Japan.

However, working in a foreign country will be considered a challenge by immigrant workers and will give more pressure to them. They have to be able to adjust to the new cultures. Migrant workers will also face socio-cultural problems such as social relations with coworkers, competition and the demands of professional work that occur in the work environment, salary issues, awards and feelings of confusion and homesickness felt by workers are often the case for migrant workers who work abroad (Kvist, 2012; Granskaya \& Lizhenkova, 2015; Kirana, 2013).

The survey which is conducted by Nugraha et al. (2017) on migrant workers in Japan shows that migrant workers are facing challenges such as differences in culture, language, the background of each individual, job demands, and expensive living costs. This condition affects the psychological health that leads to the stress of migrant workers. Besides, the Japanese culture that is considered taboo by migrant workers, the role and responsibility gaps in the workplace between Japanese culture and Indonesia, as well as the difficulties in establishing relationships with colleagues are things that can cause stress for migrant workers (Hatanaka et al., 2016).

Setyowati et al. (2010) also suggested that migrant workers in Japan experience stress and difficulty in socializing, such as feeling isolated while living in Japan and having difficulty communicating with residents. Besides, Japanese culture that is considered a taboo by migrant workers, the gap in roles and responsibilities in the workplace, and the difficulties in establishing relationships with colleagues are things that can trigger the stress of migrant workers (Hatanaka et al., 2016). Those differences such as culture, language, and habits and the lack of networks that can trigger stress on migrant workers are called acculturative stress or culture shock (Rosida, 2018). Every individual has a different way of dealing with acculturative stress. Some individuals are critical of cultural differences, adaptable to cultural differences, and begin to adopt these cultures, and some are not able to adapt to the new environment (Selmer, 1999).

In order to minimize the acculturative stress, training needs to prepare migrant workers to deal with a new environment. Pre-departure training is one of the essential preparations before migrant workers depart and to reduce their culture shock and stress level (Xia, 2009). It allows migrant workers to have knowledge about culture and learn how to behave and 
communicate correctly both in the social and business environment. If the migrant workers are not provided with knowledge about culture and how to cope with stress, then they will secede from the community and have a negative life (Murali et al., 2017). Through predeparture training, migrant workers will also be provided with how to develop their mindset for learning, giving the idea of how they have to behave, and what kind of discussion can be accepted when they are involved in a conversation.

The training also needs to be supported by soft skills, which are essential aspects that must be possessed when working. The stress experienced by the workforce depends on how the workers perceive the stress and how they deal with it. Therefore, the workers should need to have and develop potential and resilience when faced with situations where adaptability, ability to overcome problems, ability to regulate themselves, and social skills are essential. Personal resources are considered to be the most important thing and can minimize the adverse effects of stress. It also considered being able to improve adaptability in new environments (Ham et al., 2014).

Fomina et al. (2017) state that the character of each individual, such as in dealing with pressure is one of the personal resources in reducing perceived stress levels. The involvement of individuals in various activities, the ability to dealing with stress, and the ability to control complex situations also consider things that can reduce stress levels. When individuals cannot to deal with stress, such as the changes in culture, language, and also their job demands, then they tend to experience stress.

Some scholars have studied about training and stress using qualitative methods (Treven, 2003; Hurn, 2007; Xia, 2009; Setyowati et al., 2010; Ham et al., 2014; Shuttleworth, 2004). However, those studies focus on how to design a training program to minimize stress and explain how stress can affect people's psychology. Only a few studies discuss the training of migrant workers and how it affects stress at various levels of personal resources (Mayerl et al., 2017; Ayu et al., 2015). Moreover, those studies have not considered personal resources as a moderating variable that can reduce acculturative stress. Meanwhile, previous studies state that personal resources are one of the leading indicators that affect an individual's performance at work (Güler \& Çetin, 2018; Kotze, 2018; Ayu et al., 2015; Xanthopoulou et al., 2007). Thus, this study fills in the gap by examining and analyzing the influence of pre-departure training on acculturative stress with personal resources as a moderating variable. This study also expects to be an input for the government in developing training for migrant workers by considering personal resources aspects.

Based on the research background, the research questions of this research are: First, how pre-departure training affects acculturative stress? Second, how personal resources moderate the effect of pre-departure training on acculturative stress of Indonesian migrant workers in Japan?

\section{Methods}

Respondents for this research were migrant workers who were participating in an internship program in Japan since 2017. The number of respondents studied was 215 and taken from four different training institutions. The total respondents consist of 139 people 
from the Indonesian Migrant Workers Training Center (BLKPMI), 48 people from Megumi Training Institution, 19 people from Mirai Nusantara Training Institution, and nine people from Putra Maju Training Institution.

Online questionnaires were distributed to the respondents asking their perception of pre-departure training, acculturative stress, and personal resources. Respondents give alternative answers based on a Likert scale ( 1 = "strongly disagree," and 5 = "strongly agree").

Pre-departure training was measured by using a list of statements purposed by Black $\&$ Mendenhall (1989) such as "I already understand how to communicate using the Japanese well" and "I feel that the work procedures applied during the training are by the work procedures in the company where I work." (Black \& Mendenhall, 1989).

Moreover, respondents were asked a list of statements related to acculturative stress. The statements adopt from Ward et al. (2005), such as "I often feel anxious when I live in Japan.", "I always compare my native culture with culture in Japan.", and "I am always interested in learning Japanese culture." (Ward et al., 2005).

Personal resources were measured by adopting a list of the statement from Ayu et al. (2015). The statements were "I am confident in my ability to take the necessary actions.", "I have an essential role in my job.", and "I have confidence that my work can develop the potential that is within me." (Ayu et al., 2015).

This research used a quantitative research method. The statistical test conduct using Hierarchical Regression Analysis using Process Analysis purposed by Hayes (2013). The regression equation for this research is:

$$
\mathrm{AS}=\mathrm{b}_{0}+\mathrm{b}_{1} \text { PDT }+\mathrm{b}_{2} \mathrm{PR}+\mathrm{b}_{3} \mathrm{XM}+\mathrm{e}
$$

Where: AS is acculturative stress; PDT is pre-departure training; PR is a personal resource; $\mathrm{XM}$ is the interaction between pre-departure training and personal resources.

\section{Results and Discussion}

Based on the results of the reliability test conducted on each variable in the questionnaire of this study, the Cronbach Alpha value obtained was greater than 0.60 . The results show pre-departure training $(r=0.906)$, acculturative stress $(r=0.726)$, and personal resources $(r=0.897)$. Furthermore, in order to test the hypothesis, the statistical test is carried out to figure out the relationship of the independent variable toward the independent variable with a moderating variable.

The result in Table 1 shows that the p-values for each variable are lower than 0.05, which means that both the independent variable and moderating variable influence the independent variables. Furthermore, the $\mathrm{R}^{2}$ shows that the value is 0.6044 . It means that the influence on pre-departure training on acculturative stress with personal resources as a moderating variable is $60.44 \%$.

The formula of the regression equation obtained on this research is:

$$
\mathrm{AS}=2.5903-0.3265 \mathrm{PDT}-0.2615 \mathrm{PR}+0.0891 \mathrm{XM}+\mathrm{e}
$$


Table 1. Result of Process Analysis

\begin{tabular}{lccccc}
\hline & Coeff & se & $p$ & \multicolumn{2}{c}{$\mathrm{BC} 95 \% \mathrm{Cl}$} \\
\cline { 5 - 6 } Model & & & & Lower & Upper \\
\hline Constant & 2.5903 & 0.0206 & 0.0000 & 2.5498 & 2.6308 \\
Personal resources & -0.2615 & 0.0435 & 0.0000 & -0.3471 & -0.1758 \\
Pre-departure training & -0.3265 & 0.0385 & 0.0000 & -0.4024 & -0.2506 \\
$\begin{array}{l}\text { Personal resources x pre- } \\
\text { departure training }\end{array}$ & 0.0891 & 0.0356 & 0.0130 & 0.0190 & 0.1592 \\
\hline $\mathrm{R}^{2}=0.6044$ & & & & & \\
\hline
\end{tabular}

It can concluded that the constant value obtained from the results of the analysis is equal to 2.5903. It means that if the pre-departure training and personal resources variables do not influence the acculturative stress variable, the amount of acculturative stress is worth 2.5903. Furthermore, the pre-departure training regression coefficient obtained is negative, which is equal to -0.3265 . This negative value indicates that there is a unidirectional relationship between the pre-departure training and acculturative stress. It shows that every increase in pre-departure training applied by job training institutions is equal to one unit, and then it will reduce the acculturative stress level by 0.3265 . It is in line with Treven (2003) and Black \& Mendenhall (1989), who argue that one of the ways to minimize stress levels when working in a new environment is by giving training. The training should focus on crosscultural training; hence the migrant workers will be provided with skills, knowledge that is needed by the organization, and the level of stress will reduce.

Next, the regression coefficient of the moderating variable obtained is negative, which is equal to -0.2615 . This negative value indicates that there is a unidirectional relationship between personal resources to acculturative stress. It shows that every increase in personal resources by one unit it will reduce the level of acculturative stress by 0.2615 . It is in line with Ward et al. (2005), who argue that the sources of stress felt by an individual are the same. However, the levels of stress, and negative or positive that stress depends on the characteristic of the individuals. It is determined by how each views stress, how to cope with stress, individuals' flexibility towards different cultures, stress reaction, interpersonal abilities, and social abilities. The higher personal resources possessed by an individual, the lower the level of acculturative stress feels.

Last, the regression coefficient of the interaction variable between pre-departure training and personal resources obtained is positive, which is equal to 0.0891 . This positive value indicates that this interaction variable is in the same direction or can be said to strengthen the pre-departure training relationship with acculturative stress. It shows that each increase in personal resources by one unit will increase or strengthen the level of influence of the predeparture training on acculturative stress of 0.0891. It is in line with Ham et al. (2014), who argue that stress level can be minimized by providing training in advance. It aims to give the migrant workers a picture and understanding, and do not feel confused when they work in a new environment with a different culture. It is also supported by personal resources, which 
can help individuals in controlling their emotion and their work environment (Güler \& Çetin, 2018; Kotze, 2018).

Furthermore, to find out how the influence of pre-departure training on acculturative stress at different levels of personal resources can be concluded through the results of the process analysis, which shows in Table 2.

Table 2. Conditional Effect of Pre-Departure Training on Acculturative Stress

\begin{tabular}{cccccc}
\hline \multirow{2}{*}{ Personal Resources } & Effect & se & $p$ & \multicolumn{2}{c}{ BC 95\% CI } \\
\cline { 5 - 6 } & & & & Lower & Upper \\
\hline-0.5731 & -0.3775 & 0.0411 & 0.0000 & -0.4585 & -0.2966 \\
0.0000 & -0.3265 & 0.0385 & 0.0000 & -0.4024 & -0.2506 \\
0.5731 & -0.2754 & 0.0460 & 0.0000 & -0.3660 & -0.1848 \\
\hline $\mathrm{R}^{2}$-chg $=0.0118$ & & & & & \\
\hline
\end{tabular}

Notes: $R^{2}$-chg $=R^{2}$ increase due to interaction; se = standard error, $B C=$ Bias Corrected; $C l=$ Confidence Interval

Table 2 illustrates the influence of pre-departure training on acculturative stress at each level of personal resources. The p-value of less than 0.01 indicates that there is a significant influence between pre-departure training and acculturative stress at different levels of personal resources. In other words, the influence of pre-departure training on acculturative stress can occur when the level of personal resources of the individual is at a low, normal, and even high level. It proves that even though the level of personal resources is high, individuals will still feel the stress. However, the impact of stress is not as severe as it is on the lower level of personal resources.

The level of perceived acculturative stress can be seen from the value of personal resources in Table 2 . The value of -0.5731 shows a lower level of personal resources. Then in the second row shows a value of 0.0000 , which indicates that the level of personal resources is considered normal, and the value of 0.5731 on the third line shows a higher level of personal resources.

It can be concluded that when personal resources are at a lower level $(-0,5731)$, it will strengthen the influence of the pre-departure training on acculturative stress of -0.3775 . When personal resources are at the normal level (0.0000), it will strengthen the influence of the pre-departure training on acculturative stress of -0.3265 . Lastly, when personal resources are at a higher level $(0.5731)$, it will strengthen the influence of the pre-departure training on acculturative stress by -0.2754 .

For the interpretation of the moderating variable, if the higher the value of the moderating variable and its influence is more negative, then the moderating variable shows the effect that is not unidirectional or has the effect of weakening the effect of the dependent variable on the independent variable. Conversely, if the higher the value of the moderating variable and its influence is more positive, then the moderating variable shows unidirectional influence or gives an effect that strengthens the influence of the dependent variable on the independent variable. 
The result shows that when the pre-departure training level is low, the level of acculturative stress is high, and vice versa. It indicates that pre-departure training is one of the main factors that can affect the acculturative stress level of migrant workers in Japan. When the pre-departure training carried out is not adequate (low), it will have an impact on employees' acculturative stress. This finding supports the statement that pre-departure training is an essential requirement for migrant workers before participating in an international assignment. As a result, the employees' level of acculturative stress can be minimized. Therefore, the predeparture training carried out must be following matters relating to the type of work that charges later and the selection of training methods that are suitable for the objectives of the apprenticeship program (Kinkawa et al., 2012; Zheng et al., 2007).

Furthermore, this study is in line with previous studies which shows that there is a comparison between individuals who have high, medium, and low levels of personal resources. The high or low levels and positive or negative stress depends on the characteristics of the individual. It is determined by how the individual views stress, copes with stress, the flexibility towards different cultures, stress reactions, interpersonal abilities, and social abilities (Ward et al., 2005; Luthans, 2010; Wong \& Song, 2008).

Moreover, these findings are in line with the previous study that the higher the level of personal resources they have, the more negative is the influence of pre-departure training on acculturative stress. Individuals who have a high level of personal resources will have an impact on reducing stress levels. Otherwise, low personal resources tend to be more prone to stress (Güler \& Çetin, 2018; Mastenbroek, 2017; Ham et al., 2014; Hayes \& Weathington, 2007; Amatea \& Fong, 1991). It can be concluded that if the pre-departure training is effective and then supported by a good or high level of personal resources, the level of acculturative stress will be lower. The better the personal resources of an individual, the better the individual is in managing himself towards acculturative stress (Mielniczuk \& Laguna, 2017).

\section{Conclusion}

Based on the analysis, the result shows that there is a negative influence between predeparture training on acculturative stress. It shows that the more effective the pre-departure training carries out, the lower the level of the acculturative stress that feels. Furthermore, the result also shows that there is a positive influence between the pre-departure training on acculturative stress moderated by personal resources. It shows that personal resources strengthen the influence of pre-departure training on acculturative stress. The higher the personal resources owned by migrant workers, the stronger the influence of the pre-departure training on acculturative stress. These findings support the statement that personal resources are one of the leading indicators that affect an individual's performance at work.

However, this study has not discovered other variables that can be related to these variables, for instance, work engagement and job demand. The researchers also suggest conducting research related to the comparison of the acculturative stress level that is felt by female and male migrant workers since the level of acculturative stress between men and women are different. Therefore, future researches suggest expanding the subject of research. 
The research subjects were not only migrant workers from West Java but also migrant workers from other regions of Indonesia to be able to generalize the results of the study more. Furthermore, the researchers also suggest researching with respondents from other government apprenticeship programs, such as migrant workers who work in Korea. Research on Indonesian migrant workers in Korea can be done since the interest of Indonesian migrant workers to work in Korea in 2018 has increased.

\section{References}

Amatea, E. S., \& Fong, M. L. (1991). The Impact of Role Stressors and Personal Resources on the Stress Experience of Professional Women. Psychology of Women Quarterly, 15, 419-430. https://doi.org/10.1111/j.1471-6402.1991.tb00418.x.

Ayu, D. R., Maarif, S., \& Sukmawati, A. (2015). Pengaruh Job Demands, Job Resources dan Personal Resources Terhadap Work Engagement (The Impact of Job Demand, Job Resources \& Personal Resources to Work Engagement). Jurnal Aplikasi Bisnis dan Manajemen (JABM), 1 (1), 12 - 22.

Black, J. S., \& Mendenhall, M. (1989). A Practical but Theory-Based Framework for Selecting Cross-Cultural Training Methods. Human Resource Management, 28 (4), 511-539. https://doi.org/10.1002/hrm.3930280406.

Fomina, N. V., Fedoseeva, T. E., Kuimova, N. N., Ivanova, I. A., Medvedeva, T. Y., \& Salyaeva, E. Y. (2017). Personal Resources of the Professional's Stress Tolerance. Asian Journal of Pharmaceutics, 11 (3), 1-5.

Granskaya, J., \& Lizhenkova, E. (2015). Coping with Stress in Migrant Workers. Psychology and Law, 5 (4), 106-126.

Güler, M., \& Çetin, F. (2018). The Relationship Between Personal Resources and Well-being: The Role of Resource-Threatening and Resource-Consuming Factors. Management Research Review, 42(2), 199-214. https://doi.org/10.1108/MRR-01-2018-0002.

Ham, A. J., Batangan, M. T., Ignacio, R., \& Wolffers, I. (2014). Toward Healthy Migration: an Exploratory Study on the Resilience of Migrant Domestic Workers from the Philippines. Transcultural Psychiatry, 51(4), 545-565.

Hatanaka, K., Tanaka, \& Tomoko. (2016). Cross-Cultural Factors that Influence Adjustments of Foreign Care Workers in Japang: Towards a Three-Layered Structural Model. LIFE: International Journal of Health and Life-Sciences, 2 (3), 1-17.

Hayes, A. F. (2013). Introduction to Mediation, Moderation, and Conditional Process Analysis. New York: The Guilford Press.

Hurn, B. J. (2007). Pre-departure Training for International Business Managers. Industrial and Commercial Training, 39(1), 9-17.

Kinkawa, M., Hapsari, E. D., Ueda, M., \& Matsuo, H. (2012). Current Situation and Challenges in Employment of Indonesian Nursing/Certified Care Worker Candidates Based on Economic Partnership Agreement Between Indonesia and Japan. Bulletin of Health Science, 28, $31-40$. 
Kirana, R. P. (2013). Strategi Adaptasi Pekerja Jepang Terhadap Culture Shock: Studi Kasus Terhadap Pekerja Jepang di Instansi Pemerintah di Surabaya (Adaptation Strategy of Japanese Workers Against Culture Shock: Case Study of Japanese Workers in Government Agencies in Surabaya). Japanology, 1(1), 1-11.

Kotze, M. (2018). How Job Resources and Personal Resources Influence Work Engagement and Burnout. African Journal of Economic and Management Studies, 9(2), 148-164.

Kvist, A. V. (2012). Immigrant Groups, Vocational Training, and Employment. European Journal of Training and Development, 36(8), 809-826. https://doi.org/10.1108/ 03090591211263530

Luthans, F. (2010). Organizational Behavior: An Evidence-Based Approach (12th ed). New York: McGraw Hill Higher Education.

Mastenbroek, N. J. (2017). The Art of Staying Engaged: The Role of Personal Resources in The Mental Well-Being of Young Veterinary Professionals. JVME, 44(1), 84-94.

Mayerl, H., Stolz, E., Großschädl, F., Rásky, É., \& Freidl, W. (2017). The Moderating Role of Personal Resources in The Relationship Between Psychosocial Job Demands and Health: a Cross-Sectional Study. BMJ Open Journals, 7(8), 1-10. https://doi.org/ 10.1136/bmjopen-2016-015710.

Mielniczuk, E., \& Laguna, M. E. (2017). Motivation and Training Initiation: Evidence From Poland. Journal of Workplace Learning, 29 (1), 1-29. https://doi.org/ 10.1108/JWL-012016-0002

Murali, S. B., Basit, A., \& Hassan, Z. (2017). Impact of Job Stress on Employee Performance. International Journal of Accounting \& Business Management, 5(2), 13-33.

Nugraha, S., Honda, S., \& Hirano, Y. (2017). The Change in Mental Health Status of Indonesian Health Care Migrant Worker in Japan. Kesmas: National Public Health Journal, 12 (2), 53-59.

Rosida, A. (2018). Analysis of Culture Shock Experienced Towards Indonesian Sailors in Overseas. IOP Conference Series: Earth and Environmental Science, 156, 1-7.

Selmer, J. (1999). Culture Shock in China? Adjustment Pattern of Western Expatriate Business Managers. International Business Review, 8(5-6), 515-534. https://doi.org/ 10.1016/S0969-5931(99)00018-9.

Setyowati, S. H., Yetti, K., Hirano, Y. O., \& Kawaguchi, Y. (2010). The Experiences of Indonesian Nurses in Japan Who Face Job and Cultural Stress in Their Work: a Qualitative Study. Bulletin of Kyushu University Asia Center, 5, 175-181. https://doi. org/10.15017/17936.

Shuttleworth, A. (2004). Managing Workplace Stress: How Training Can Help. Industrial and Commercial Training, 36(2), 61 - 65. https://doi.org/10.1108/00197850410524824.

Treven, S. (2003). International Training: The Training of Managers for Assignment Abroad. Education + Training, 45 (8/9), 550-557. https://doi.org/10.1108/ 00400910310508937.

Ward, C., Bochner, S., \& Furnham, A. (2005). The Psychology of Culture Shock (Second ed.). Philadelphia: Routledge. 
Wong, D. F., \& Song, H. X. (2008). The Resilience of Migrant Workers in Shanghai China: The Roles of Migration Stress and Meaning of Migration. International Journal of Social Psychiatry, 54 (2), 131-143. https://doi.org/10.1177/0020764007083877.

Xanthopoulou, D., Bakker, A. B., Demerouti, E., \& Schaufeli, W. B. (2007). The Role of Personal Resources in the Job Demands-Resources Model. International Journal of Stress Management, 14 (2), 121-141.

Xia, J. (2009). Analysis of Impact of Culture Shock on Individual Psychology. International Journal of Psychological Studies, 1(2), 97-101.

Zheng, C., Hyland, P., \& Soosay, C. (2007). Training Practices of Multinational Companies in Asia. Journal of European Industrial Training, 31(6), 472-494. https://doi.org/ 10.1108/03090590710772659. 